\title{
HOW BRIAN GRAY BECAME A COMBUSTION SCIENTIST
}

\author{
HUW O. PRITCHARD \\ Department of Chemistry, York University, Toronto M3J 1P3, Canada.
}

I regret not being able to attend this celebration of Brian Gray's retirement, for I could have related many anecdotes about him, such as "why did the barman push the revolving door of the College Arms out into the street?" However, I am grateful for this opportunity to tell you a little about his early days as a scientist.

Upon graduation in 1954, he chose me as his Ph.D. supervisor. I was not regarded as much of a theoretical chemist at that time and it was deemed from above that he would do an experimental project. It turned out to be a fairly intractable one, and neither of us had the desire to continue it, so he wrote it up for his M.Sc. Meanwhile, he had been telling me all kinds of neat things that he had learned about quantum mechanics-and which I did not know-so he began to explore some of his new ideas which, by and large, I observed benignly.

A clever one was that of calculating the properties of $\mathrm{H}^{-}$from $\mathrm{H}_{2}^{+}$wave functions, essentially turning the Born-Oppenheimer separation inside out. This was included in his Ph.D. thesis among an assortment of other imaginative topics. The head of Department chose Charles Coulson to be the External Examiner, but he claimed later to be too busy and passed the thesis on to Christopher Longuet-Higgins. HCL-H had been a member of our Department previously, and arrived from London in time for lunch, over which we chatted about inconsequential things. Then, going up the steps to the examination room, 10 minutes before the Oral Examination was due to start, he said "Well, Huw, I have to tell you I am going to fail this student" at which I was aghast. The logic was that the Born-Oppenheimer separation was a perturbation expansion in $(m / M)^{1 / 4}$ and since $M \sim 2000 m$, if you turned it upside down, it must diverge.

The examination proceeded relatively sedately until we came to this topic, whereupon the temperature rose considerably-I will always remember one exchange: "Now listen here, laddy; I'm the Examiner, I ask the questions!" Among the rules of procedure at that time were that (a) the Supervisor was strictly an observer, and (b) the thesis was submitted already bound, in final form. All officials present sided with the External Examiner, who eventually conceded that he would allow the thesis to pass if the offending chapter and all references to it were to be removed.

This was Thursday, and the following Tuesday Brian was sailing from Southampton to take up a Post-doctoral Fellowship with Linus Pauling at CalTech-one condition being that "all of the requirements for the award of the $\mathrm{Ph}$.D. must have been fulfilled". I, too, was sailing on the same boat to spend my first sabbatical, also at CalTech, with Norman Davidson. So we repaired to the College Arms, wanting to fight against the decision, but accepting that there was no choice but to cut out the offending chapter 
with a pair of scissors. Of course, two weeks later, Pauling thought it was a great idea, and it has been used by others since that time, for example R. S. Berry, in the treatment of excited states of 2-electron atoms.

Ten years later, after we had finally proved the idea to be correct, I wrote to the Ph.D. Committee in Manchester asking to have the excised pages restored, but they took the easy way out: " ... that since the thesis deposited in the Library represents the record of the candidate's research work on which the degree of Ph.D. was awarded, it is precluded from permitting any amendments to the thesis to be made." However, I still have, and treat with care, my unexpurgated edition of the thesis!

On our return to England, me back to my job and he to a post-doctoral position, it soon became clear that he would never secure an academic post in theoretical chemistry - he was too unconventional a thinker and my judgement was suspect for going along with it, so that my support was more of a hindrance. I had, following my sojourn with Norman Davidson, become interested in solving non-equilibrium chemical kinetic problems by computer, and persuaded Brian that if he had any future in Britain in theoretical chemistry, it would not be in the conventional areas, but in some new one, such as this. Soon, he left for the Defense Research Corporation in Santa Barbara where, almost immediately, he found that he had to generate his own salary through research contracts. A proposal in combustion kinetics filled the bill, and before long, he wrote his ground-breaking papers on branching chains in combustion processes, which set him on the trail that is being celebrated at this Meeting.

However, he never completely forsook experimental chemistry, and I have observed, from time to time, some nicely executed experiments (for example on the spontaneous ignition of bagasse)-so what he learnt with me in that very first year as a Research Student was not ever totally lost! 